\title{
進化生物学と 統計科学：系統樹の推定をめぐって Statistical Sciences and Evolutionary Biology with Special Reference to Phylogeny Estimation
}

\author{
三中信宏 \\ Nobuhiro Minaka \\ 農業環境技術研究所 \\ National Institute for Agro-Environmental Sciences
}

\begin{abstract}
Contemporary evolutionary biology has used various statistical methods for collecting and analyzing data. Here methods for estimating phylogenetic trees are reviewed in the context of recent history of evolutionary biology, especially of systematics and phylogenetics. Estimating evolutionary history based on character data (molecular or morphological) poses a couple of epistemological problems all of which are common to historical sciences in general. Karl Popper's philosophy of science, in particular, his theory of falsification and corroboration has been espoused by many theoretical phylogeneticists. In this paper the long-standing controversy on philosophical aspects of phylogenetics and its implications for statistical methods in this discipline is discussed.
\end{abstract}

1. 進化学の現代的総合: その統計科学との接点について

過去 1 世紀に及、3統計科学の歴史を振り返ると，自然科学から社会科学にいたるさまざまな学 問分野において，基礎から応用まで幅広い問題を解決する上で大きく貢献してきたことがわかる． 現象光れ自体がもつ確率的な変異性の程度と光れがデータに反映されたときの定量的な分析を考 える上で , 統計学のさまざまな概念や方法や理論が役に立ってきたことを疑う余地はない .とく に，生物学の中でも進化生物学の現代史は多くの局面で統計科学との接点をもってきた .

チャールズ・ダーウィンの進化理論が提唱された後, 彼のいとこだったフランシス・ゴルトン が生物統計学の基盤を築いた 19 世紀後半以降の生物学史的エピソードのいくつかは進化学と統計 学との結びつきの深さを如実に物語っている . 弚の中でも , ゴルトンの弟子のカール・ピアソン が率いる生物測定学派 (biometricians) とメンデルの論文が再発見されて以来大きく発展したメ ンデル遺伝学派 (Mendelians) との間で闘わされた生物進化の基本プロセスをめぐる論争は特筆 されるべきである.なぜなら，20世紀初頭のこの論争か契機のひとつとなって，1930〜 40 年代に かけての「現代的総合」(The Modern Synthesis) につながり，自然淘汰理論に基づく現在の進化 生物学の基本路線の確立をもたらしたと言えるからである

ダーウィンが 1882 年に世を去り，世紀末を迎えたダーウィン理論はいったん衰退することにな る.衰退したのは進化学や系統学ばかりではなく，ナチュラル・ヒストリーの分野全般に活気が なくなったと言われている . 弚の一因は, 同時代の実験的手法に基づく発生学や遺伝学に研究者 の注目が集まったためだろう. 学問的運動としての進化学の現代的総合は, 弚れを主導した生物 Jpn J Biomet Vol. 28, Special Issue 1, 2007 
学者たち (エルンスト・マイヤー, ジョージ・ $G$ ・シンプソン , テオドシウス・ドブジャンスキー ら ) にとっては, 世紀末から低迷し続けていたナチュラル・ヒストリーに対する大胆な梃入れを 意図していた .

しかし , ナチュラル・ヒストリー復興の拠り所となるはずの現代的総合は, 学問的にけっして 統一されてはいなかった . 実際 , もつとも基盤的な進化過程の理論づくりに貢献した理論集団遺 伝学者の中には, ロナルド・A・フィッシャーのように現代数理統計学を確立した科学者が含まれ ていた . 彼らは, 厳密な数理モデルに基づく統計学の理論が進化研究の中核にあるべきだと考え ていた . 自然淘汰の数学理論は上記のフィツシャーやセウォール・ライトによって 1940〜 50 年代 にはすでに十分に深められていた . さらに言えば , 後に分子進化の中立説を提唱することになる 木村資生が 1950〜 60 年代にかけて日本語で著した理論集団遺伝学の著作（木村 1957，1960）は 徹底的な数学的厳密さを特徵としていた . 確率論や統計学か現代進化学にとって欠くことができ ない理論となった所以である。

一方, 進化現象をミクロの遺伝子レベルで追究しようとする理論集団遺伝学派の思潮に対して， ナチュラル・ヒストリーの復興を目指したマイヤーらは, 今日的な言葉でいえばマクロ生物学を目 指し, 生物個体の集団に関する研究こ光重要だという見解を打ち出した．マイヤーが 1940 年代に 提唱した集団的思考 (population thinking) ならびに生物学的種概念 (biological species concept) は現代的総合のマクロ生物学的な側面の現われであるとみなすことができる . マクロな進化現象 を論じる理論的なよりどころをマイヤーたちは確立しようとしたのである .

ダーウィンの生きた 19 世紀は生物の遺伝現象に関する統計学的議論はまだ萌芽的だった．しか し, 兴の後の生物測定学や数理統計学の発展を背景にして, 世代間の遺伝子の伝達や午の頻度の 動態に関する理論的研究は進んだ. 产れでは, 钅のような遺伝学的研究以外の分野での統計科学 との接点はどのようなものだったのだろうか .

たとえば, 生物多樣性を研究対象とする体系学 (systematics) にかぎるならば, 分類学におけ る統計学的手法の応用は現代的総合と次代を同じくして，いくつかの状況で現れた . 古生物学者 ジョージ・ G・シンプソンは当時の動物学者としては例外的に数学に長けていて , 1930 年代には 早くも『定量動物学 (Quantitative Zoology)』(Simpson and Roe 1939) という本を著し，比較 的単純なパラメトリック統計学 (主として単変量を対象とする方法) を適用するだけでも，ナチュ ラル・ヒストリーの研究は大きく進展するという論陣を張った .

これに対して，1950 年代末に多変量解析の一手法であるクラスター分析を開発した統計学者 ロバート・R・ソーカルとピーター・H・A・スニースは, シンプソン流の単純な統計的手法では 不十分であり, 当時ようやく実用に供されるようになったコンピュータを用いた複雑かつ大規模 な多変量解析の諸手法を武器にして, 生物分類体系を客観的に構築すべきであるという数量分類 学 (numerical taxonomy) あるいは数量表形学 (numerical phenetics) を押し進めた (Sokal and Sneath 1963 『数量分類学の原理 (Principles of Numerical Taxonomy)』).1960 年代に入ると， この数量分類学をめぐる論争はさらに拡大し, 後述の系統関係にしたがって生物分類を構築すべ きだとする進化分類学派 (evolutionary taxonomy) や分岐分類学派 (cladistics) との間で 20 年 にも及ぶ三つ巴の戦いとなった（Hull 1988, 三中 1997, 2005) . 
1980 年代には生物分類学をめぐる論議は終息し, 数量分類学派は生物分類以外の分野に進出し ていった . 今もなお版を重ねているソーカルと F・J・ロールフ『生物統計学 (Biometry)』(Sokal and Rohlf 1969) に代表されるように, 進化研究にかぎらず生物学の分野で統計学的手法を広く普 及させたのは数量分類学派の大きな貢献の一つといえるだろう.さらに最近の研究動向に目を向 けると, 近年の形態測定学 (morphometrics) の理論的発展には, もと数量分類学派の研究者が多 数関わっている (三中 1999) .「かたち」の統計学は, サイズを標準化したシェイプがケンドール 形状空間というリーマン多樣体を構成するため，厳密には非線形の球面統計学を必要とする (接 平面に射影すれば近似的には線形統計学が適用可能である) . 古くはダーシー・W・トムソンの古 典『On Growth and Form』(1942) 以来，「かたち」の定量的分析と光の変形の数学的記述は比較 形態学の大きな問題だった . 乥れが, 統計学の発展理論を用いることによりようやくデータ解析 のツールとして使えるようになったのも統計学の大きな貢献のひとつと言うべきだろう .

しかし，生物多樣性を論じる学問は分類学だけではない．現在目にするおびただしい数の生物 たちは進化の産物である．もしもわれわれにこれらの生物の過去の進化史 (系統発生) を推定す る手法が与えられたならば, データから推定された系統樹を用いて多樣な生物を体系化すること ができるだろう．以下では，現代的総合の中でも，とくに系統推定 (phylogeny reconstruction) すなわち生物の系統関係を推定するという研究領域に焦点を絞り，乥れが並走して発展してきた 統計科学の諸理論とどのような相互関係を及ぼしてきたのかについて述べる .

\section{2. 過去を復元する : 歴史は科学の対象なのか}

過去の歴史を推定するという作業は認識論的な問題をわれわれに提起する.生物の進化史の推 定と人間社会の歴史の復元は, 弚れを対象とする学問分野が文理にまたがっているという表層的 なちがいを除けばまったく同じ問題状況にある．すなわち，いかにすれば過去の事象に関する仮 説は経験的にテストできるのかという問題である . 古生物学者スティーヴン・J・グールドは, 歴 史はまっとうな科学研究の対象であると主張する :

「歴史を推論することは，すべての進化研究にとって不可欠であるにもかかわらず, 信頼性 に問題があったため，真に科学的な観点から過去を探究する上での障害となっていた．ダー ウィンは, ガリレオが木星の月を観察したのに匹敵する信頼度で歴史を推論する方法が確立 され例証されないかぎり，進化学はまともに扱ってもらえないだろうと考えた．弚れが彼を して歴史の推論規則を定式化させるきっかけになったのだ . 私は『種の起源』こ乥この規則 を例証するひとつの長い論議だとみなしている . 歴史の推論は, 事実としての進化の立証な らびにメカニズムとしての自然淘汰の擁護の背後にあるもっと一般的な論点を提示している」 (グールド 2002: 99)

自然科学の研究者の中には，いまだに「歴史研究はサイエンスではない」という誤解が広まっ ている.これに抗して , グールドは進化生物学が科学一般に投げかけた強力なメッセージは歴史 が科学の研究対象となり得ることを示した点にあると指摘する：

「まずはじめに歴史があることが他科学に進化論が与えた教訓であるならば，われわれは，科 学の名に值しないただの叙述だからという理由で歴史を見捨てるのではなく，むしろ法則や 
類似性を探る源としての歴史を尊重し光の意義を追究すべきである」(グールド 1986: 68)

しかし，実験科学と比較してみればすぐにわかるように，歴史の研究は光れが生物の系統発生 であれ人間社会の進化であれ，科学としての性格が実験科学とは著しく異なっていることは誰の 目にも明らかだろう. 典型的な実験科学では，観察可能性・実験可能性・反復可能性・予測可能 性・一般化可能性など，直接的なデータ取得によって対象に関する仮説を経験的にテストするこ とが容易である．しかし，進化学のような歴史科学では，光れらの条件のいずれもが当てはまら ないことがほとんどだ .とすると，生物の過去に関する推論を行う系統推定を実行するためには， 仮説の良し悪しをデータに基づいて判断する基準を与える必要があることになる．

母集団からサンプルされた無作為標本から標本平均か計算できるように , 形質集団からサンプ ルされたデータに基づいて推論された系統樹は統計学的な意味での「推定値」である.離散構造 として定義される系統樹の総数は問題のサイズによって明示的に計算できるので，ここでの問題 は, 弚れらの対立仮説の間の選択をする基準をどのようにして与えればいいのかという点である．

\section{3. アブダクション：仮説選択の相対的基準として}

古典的な科学哲学では, 演繹 (deduction) と帰納 (induction) という二種類の推論スタイルが ある . 演繹とは，前提となるある主張から論理的に別の主張を導くというタイプの推論である . 方 , 帰納とは, 観察データの蓄積により, 真なる普遍法則を導くというタイプの推論である .ここ での重要な論点は,「データと理論の間にはどのような関係があるのか」という問題である . 経験 (データ) に照らすことが科学にとっては不可欠である．しかし，光の主張は経験 (データ) か完 全無欠であるということを意味してはいない，仮説がまちがう可能性があると同時に，観察デー タもまた誤りや不確かさを含んでいるかもしれない .このことは，統計的な思考のもとではごく 自然に受け入れられるだろう．データに照らして整合的な仮説は「真」であり，矛盾する仮説は 「偽」であるという解釈は，データがつねに完全無欠であるという前提を置いている．しかし，光 の前提はしばしば破られる．現実には，完全無欠なデータは存在しないからである．

歴史学者カルロ・ギンズブルグはデータがもつ情報的価值について次のように言う：

「資料は実証主義者たちが信じているように開かれた空でもなければ，懷疑論者たちが主張 するような視界をさまたげる壁でもない，いってみれば，光れらは歪んだガラスにたとえる ことができるのだ」(ギンズブルグ 2000: 48)

ギンズブルグはデータを鵜吞みにしたり頭から拒否することなく目の前のデータ (資料) を批 判的に検討しつつ，データが仮説に対してもつ証拠として価値を認める：

「ひとは証拠を逆撫でしながら，光れをつくりだした者たちの意図にさからって，読むすべ を学ばなければならない」(ギンズブルグ 2000: 46)

データという “歪んだガラス”を通して見るということは，データと仮説のいずれに対しても 「真偽」を問うことなく，もつと弱い論理的関係を両者の間に置くことである．乥れはまた，観察 データが個々の対立仮説に対してさまざまな程度で与える経験的支持の大きさによって仮説の相 対的ランキングをするという意味でもある．証拠としてのデータが仮説に与える経験的支持は， 演繹や帰納が含意する論理的真偽に比べればはるかに弱い関係だが，弚れでもなおデータによる 
仮説の選択力は失われてはいない . われわれは証拠によってより強く支持される仮説を選ぶ゙とい う基準を置くことができるからである．

データと理論の間に想定されるこの弱い関係は，演繹でも帰納でもない第三の推論樣式とみな すことができる . 乥れは , アリストテレスのいう「エンテュメーマ」すなわち「最善の説明に向 けての推理」(ギンズブルグ 2000: 67) に始まり，19 世紀の哲学者チャールズ・S・パースの提唱 する「アブダクション (abduction) 」に連なる推論の系譜に属している.要点は, 理論や仮説の 真偽を問うのではなく，観察されたデータのもとでいずれが「より良い説明」を与えるかを相互 比較するという点にある．

この軸足の移行は数理統計学においても見られる .これまで典型科学とみなされてきた実験系 の物理学や化学では, 物理現象や化学反応に関する仮説は適切な実験と観察を行なえば経験的 にテストすることが可能である .すべての仮説は経験的なテストを通じて光の真偽を判定するこ とができるというのは, ルドルフ・カルナップの論理経験主義であろうが , カール・ポパーの反 証主義であろうが , 共通して掲げられていた旗印だった . 提唱された経験的仮説の運命は , デー タによって確証 (confirm) されることにより，あるいは反証 (falsify) されることにより，关の “生死”が決まった . 実際 , かつて 1933 年に定式化されたネイマンーピアソン流の仮説検定の枠組 みは, データによる意思決定すなわち仮説の棄却と受容のための行動基準を与えた . これに対し て , データを仮説の相対的価值を評価する証拠 (evidence) とみな光うとする新しい枠組みがい まできつつある (Royall 1997, Taper and Lele 2004) .

アブダクションによる仮説選択は, 歴史科学としての系統推定論の根幹であり，同時に統計科 学との深いつながりが見られる (Sober 1988)．系統樹を構築するためのデータとは,さまざまな 形質情報である . 弚れは従来から蓄積されてきた形態や行動のデータもあるが，近年では DNA や蛋白質の分子配列情報を利用した分子系統学が急速に普及している．これらの形質情報をデー タとして，どの系統樹をべストと判定するかが系統推定におけるアブダクションの目標となる .

推論プロセスとしてのアブダクションのしくみを具体的に書き下すと次のようになる：

1) データ D がある .

2) ある仮説 H はデータ D を説明できる .

3） $\mathrm{H}$ 以外のすべての対立仮説 $\mathrm{H}^{\prime}$ は $\mathrm{H}$ ほどうまく D を説明できない .

4) したがって，仮説 H を受け入れる.

このように箇条書きにすると，アブダクションと他の推論樣式 (演繹と帰納) とのちがいがはっ きりわかる . 演繹と帰納は，ある意味で対極的な推論樣式だが，データのみから仮説の真偽を判 定するという点ではちがいがない，一方，アブダクションは，他の対立仮説との相対的比較すな わち競争が要求されるという点で決定的なちがいがある. 与えられたデータのもとでの仮説間の 競争は, アブダクションは終わりのない推測の連鎖であることを意味する . 新しいデータが付け 加わつたり，あるいは新たにつくられた対立仮説との比較により，これまでの推測が覆される可 能性はいつでもある . 
4. 系統樹をテストするとはどういうことか：仮説の験証度と論理的確率 カール・ポパーは炎の著書『開かれた社会と午の敵』の第 2 部の中で, 普遍法則の発見を目指 す一般化科学 (generalizing sciences) や普遍法則に基づく将来予測を目指す応用科学 (applied sciences) と，歴史科学 (historical sciences) とのちがいを次のように述べている：

「原則的に, われわれか特殊な出来事と弚の説明に関心を抱いているならば，われわれは必 要とされているあまたの普遍法則を当然視するのである.さて, 特殊な出来事および光の説 明にこのような関心を抱いている科学は, 一般化科学からは鋭く区別して, 歴史科学と呼べ

よう」(Popper 1966: 264; 訳書, p. 245)

ポパーの言う歴史科学の性格は, 本稿て論じてきた系統推定論に弚のまま当てはまる。では, 歴 史科学の仮説 (ここでは系統樹) は, ポパーの反証理論（仮説演繹主義）に基づいてどのように テストされるのだろうか．ポパー自身は，一般化科学における普遍言明 (普遍クラスに関する言 明) だけが反証可能であるとは考えていなかった . 実際 , 歴史科学の言明もまた反証可能である ことは, 彼自身が指摘している:

「古生物学, 地球上の生命の進化史, 文学史, 技術史, 科学史のような歴史科学は科学として の性格をもたないと私が主張したように考えている人がいる。かし，乥れはまちがいであ る.私の考えではこういう歴史科学は科学としての性格を備えているのだ. 私は光れを喜ん で認めよう . 多くの場合, 歴史科学の仮説はテスト可能である . 歴史科学は個別事象 unique events を記述するがゆえにテスト不可能であるかのごとく考えている者が見受けられる．けれ ども , 個別事象の記述は, ほとんどの場合乥れらの記述からテスト可能な将来予測 prediction もしくは過去予測 postdiction を導出すればテストは可能なのである (Popper 1980: 611) 進化生物学にとって必要なのは, 生物進化の仮説のテストがどのような手だてによって可能に なるのかを考察することである．

以下では，仮説の験証度 (degree of corroboration) に関する理論 (Popper 1968b，1983) に 則って，系統推定における系統関係の仮説すなわち系統樹 $(\mathrm{h})$ と形質情報の証拠 (e) ならびに 背景的知識 (b) との関係を定式化する (Helfenbein and DeSalle 2005, Faith 2006 参照). 背景 的知識 (background knowledge) とは,「理論をテストする間は, 問題のないものとして (仮に) 受け入れる事柄すべて」(Popper 1968b, 訳書 p.435) である.系統学での背景的知識とは，た とえば「生物進化が生じた」という根本仮定を指している．与えられた形質データ (e) がある 系統樹 (h) に対して与える支持の程度は，条件付き確率 (Popper 1968a の言う相対的確率) の 差 $\mathrm{p}(\mathrm{e}, \mathrm{hb})-\mathrm{p}(\mathrm{e}, \mathrm{b})$ で表わされる .ここでの「確率」とは, 数理統計学で用いられる事象の頻度 的確率でもべイズ的な主観的確率でもなく，命題のもつ論理的確率である (Popper 1968a, 訳書, pp. 149-150) . 上式での p (e,b) はbによって条件づけられた e の論理的確率であり, p e,hb) は $\mathrm{hb}$ すなわち $\mathrm{h}$ かつ b という連言命題によって条件づけられた e の論理的確率である . これらの 条件付き確率の差 $\mathrm{p}(\mathrm{e}, \mathrm{hb})-\mathrm{p}(\mathrm{e}, \mathrm{b})$ は，共通の背景的知識 (生物進化上の仮定) のもとで，ある 系統樹がデータに対して与える条件付き確率の差である .

この条件付き確率の差 $\mathrm{p}(\mathrm{e}, \mathrm{hb})-\mathrm{p}(\mathrm{e}, \mathrm{b})$ にある係数を乗じ , 光の值の範囲が -1 〜 +1 となるよう に補正した数值 $\mathrm{C}(\mathrm{h}, \mathrm{e}, \mathrm{b})=\{\mathrm{p}(\mathrm{e}, \mathrm{hb})-\mathrm{p}(\mathrm{e}, \mathrm{b})\} /\{\mathrm{p}(\mathrm{e}, \mathrm{hb})-\mathrm{p}(\mathrm{eh}, \mathrm{b})+\mathrm{p}(\mathrm{e}, \mathrm{b})\}$ を背景的知識 $\mathrm{b}$ の 
もとでの証拠 e による仮説 h の「験証度 (degree of corroboration)」と定義する (Popper 1983: 240）. 験証度の分子は上述の確率差であり，分母は補正係数である . 条件付き確率の定義により 験証度の分母第 2 項は, $\mathrm{p}(\mathrm{eh}, \mathrm{b})=\mathrm{p}(\mathrm{e}, \mathrm{hb}) \times \mathrm{p}(\mathrm{e}, \mathrm{b})$ と変形できる．したがって，験証度 $\mathrm{C}(\mathrm{h}, \mathrm{e}, \mathrm{b})$ は $\mathrm{p}(\mathrm{e}, \mathrm{hb})$ および $\mathrm{p}(\mathrm{e}, \mathrm{b})$ の 2 つの確率值によって完全に決定されることがわかる .

ある系統樹 $\mathrm{h}$ の験証度を増加させるためには, 上式の分子第 1 項 $\mathrm{p}(\mathrm{e}, \mathrm{hb})$ の值を大きくすると 同時に，第 2 項 $\mathrm{p}(\mathrm{e}, \mathrm{b})$ の值を小さくする必要がある. 第 1 項は，個々の系統樹が形質データに対 して与える確率であるから，系統樹ごとに关の值は異なり，データとの整合性が高い系統樹ほど 高い値をとる . ポパーの反証主義のもとでの系統樹の相対的選択は, 上で示したように験証度の 最大化を目指せばよい .この仮説選択基準は, 必要最低限の背景知識 $\mathrm{b}$ のもとで , 形質間のホモ ロジー (共通祖先に由来する相同性) を最大化し，光れと同時に形質データ e を説明するための アドホックなホモプラジー (同じ形質状態が別々に進化する非相同性) を最少化する系統樹 $\mathrm{h}$ を 選択することで実現される．

\section{5. 統計学的系統学の時代の到来が意味するもの}

21 世紀に入り，系統樹の経験的テストという論点に新しい軸が付け加わつた . 光れは, 1990 年 代以降の分子系統学における統計学的方法の発展と, 弚れにともなうモデルベースの系統推定に 対する関心の高まりである (Felsenstein 2004, Yang 2006). 最尤法やベイズ法など明示的な確率 モデルに基づく統計学的方法の適用は, 高速なコンピュータの普及とマルコフ連鎖モンテカルロ (MCMC) のような効率的な探索アルゴリズムの開発により，進化生物学のさまざまな分野で利 用されるようになってきた．系統推定論も炎の例外ではない．1980 年代以降しだいに普及した最 尤法 , あるいは 1990 年代末から急速に浸透したベイジアン MCMC 法を用いた系統樹の推定は， 今では系統推定の標準的なツールとなっている .

このような新しい手法の開発と普及は, 系統推定の方法論間の新たな論争を生むことになった . 前節で論じた系統樹に関する験証度の理論は，もともと分岐学派 (claditics) に基づく最節約法 の支持者が最節約原理のもとでもつとも単純な系統樹を選択するという最適性基準を正当化する ためにもちだしてきた。しかし，ポパーがもともと論理的確率によって定義した験証度を，頻度 的確率によって再解釈すれば系統推定における最尤法もまたポパーの科学哲学 (反証主義) の枠 内でとらえ直すことができるだろうという主張がなされている (de Queiroz \& Poe 2001, 2003) . もし最尤法が反証主義であると解釈できるとすると，やはり反証主義を長らく標榜してきた最節 約法 (分岐学派) との関係はどのようになるのか. 実際 , この主張に対する分岐学派からの反論 は相当に激しい (Kluge 2001; Faith \& Trueman 2001; Farris et al. 2001; Siddall 2001, Rieppel 2003). しかし，系統推定の方法論としての最尤法と最節約法に関する数理的研究 (Penny et al. 1994; Tuffley \& Steel 1997; Steel \& Penny 2000) を踏まえると, 両者は根本的に両立し得ない理 論体系ではないだろう.

実際の系統推定の作業の観点からいえば，むしろ，系統推定のための背景的仮定 (b) をどのよ うに置くのかという問題の方が重要だろう（Siddall and Kluge 1997）．とりわけ，モデル・ベー スな系統推定法 (最尤法やべイズ法) ではさまざまな背景的仮定を置くことが光れらの手法を実 
行する上での前提となっている．系統樹の験証度に戻ると，第 1 項を構成する論理的確率 $\mathrm{p}(\mathrm{e}, \mathrm{hb})$ の值は系統樹 $\mathrm{h}$ と形質データ e との整合性に比例して兴の值が決まる．しかし，仮説 $\mathrm{h}$ の験証度 を上げるためには，第 2 項の論理的確率 $\mathrm{p}(\mathrm{e}, \mathrm{b})$ の值も同時に小さくする必要がある .これは, 背 景的仮定 $\mathrm{b}$ を最少にとどめることにより実現できる .この点を考えたとき，モデル・ベースな系 統推定法は塩基置換モデルやさまざまな事前確率に関するモデル) を積み重ねるために，どうし ても $\mathrm{p}(\mathrm{e}, \mathrm{b})$ 值が大きくなり，結果として系統樹の験証度は低下してしまうだろう．

生物が進化したというような根本的な仮定は光れを前提としなければ，形質データと系統樹と の認識論的つながりが断たれてしまう．また，分子進化における DNA 塩基置換の確率モデルに 関する知見もすでに繰り返し裏づけられた経験的論拠のある知識であるみなしてかまわないだろ う.では，乥れ以上の背景的仮定はどこまで許容できるのだろうか．背景的知識の多くは，まだ テストの対象となってはいない仮説群にすぎない . 炎れらの裏付けと検討をさらに重ねることは 系統推定論にとって今後の重要な課題と言えるだろう. 現実的なモデルの採用と光れがもたらす 験証度の低下とのトレードオフを回避するためには，仮定するモデルを必要最小限に抑えるとい うモデル選択論的な制約がどうしても必要になるだろう.

\section{6. 最後に：さらに広がる進化生物学と統計科学との交わり}

本稿では, 現代の進化生物学の広大な領域の中で, とくに系統推定論と統計科学との交流に焦 点を当てて概観してきた . 生物の歴史を研究対象とし, 過去を推論しようとするとき, 進化学者 は科学哲学と統計科学とをまたにかけて論陣を張ってきた。弚の一世紀に及、現代史を振り返る とき, 学問の間の豊かな交わりとはどうあるべきかについて深く考えないわけにはいかない．し かも, 進化学と統計学との結びつきは今なおきわめて強いし, 兴の傾向は当面続くだろう. 進化 生物学者は統計学をツールとして自らが直面する問題を解こうと奮闘し，一方の統計学者は進化 生物学が提示する問題群を解くことで統計的手法をさらに洗練させ , 生物進化をひとつの実験場 として統計理論の鍛え上げを実践してきた .このような相利的なやりとりが実を結ぶかぎり，進 化学と統計学との越境的交流はこれからも続いていくだろう.

\section{参 考 文 献}

Faith, D. P. (2006). Science and philosophy for molecular systematics: Which is the cart and which is the horse? Molecular Phylogenetics and Evolution, 38: 553-557.

Faith, D. P. and Trueman, J. W. H. (2001). Towards an inclusive philosophy for phylogenetic inference. Systematic Biology, 50: 331-350.

Farris, J. S., Kluge, A. G. and Carpenter, J. M. (2001). Popper and likelihood versus "Popper*". Systematic Biology, 50: 438-444.

Felsenstein, J. (2004). Inferring Phylogenies. Sinauer Associates.

Ginzburg, C. (2000). Rapporti di Forza: Storia, Retorica, Prova. Giangiacomo Feltrinelli Editore. [上村忠男訳 (2001). 歴史・レトリック・立証. みすず書房.] 
Gould, S. J. (1986). Evolution and the triumph of homology, or why history matters. American Scientist, 74: 60-69.

Gould, S. J. (2002). The Structure of Evolutionary Theory. Harvard University Press.

Helfenbein, K. G. and DeSalle, R. (2005). Falsifications and corroborations: Karl Popper's influence on systematics. Molecular Phylogenetics and Evolution, 35: 271-280. [Corrigendum (2005): Ibid. 36: 200]

Hull, D. L. (1988). Science as a Process : An Evolutionary Account of the Social and Conceptual Development of Science. University of Chicago Press.

木村資生 (1957). 集団遺伝学の数学的理論. 岩波講座 ·現代応用数学 B.11, 岩波書店.

木村資生 (1960). 集団遺伝学概論 . 培風館 .

Kluge, A. G. (2001). Philosophical conjectures and their refutations. Systematic Biology, 50: 322-330.

三中信宏 (1997). 生物系統学, 東京大学出版会.

三中信宏 (1999). 形態測定学. Pp. 61-99 所収 : 棚部一成·森啓編 (1999). 古生物の科学・第 2 巻 : 古生物の形態と解析. 朝倉書店 .

三中信宏 (2005). Ernst Mayr と Willi Hennig : 生物体系学論争をふたたび鳥瞰する. タクサ, 19: 95-101.

三中信宏 (2006). 系統樹思考の世界 : すべてはツリーとともに. 講談社.

Penny, D., Lockhart, P. J., Steel, M. A. and Hendy, M. D. (1994). The role of models in reconstructing evolutionary trees. R. W. Scotland, D. J. Siebert and D. M. Williams (eds.), Models in Phylogeny Reconstruction. Oxford University Press. Pp.211-230.

Popper, K. R. (1966). The Open Society and Its Enemies, Vol.2. The High Tide of Prophecy: Hegel, Marx, and Aftermath. 5th Ed. Routledge \& Kegan Paul [小河原誠・内田詔夫訳 (1980). 開かれた社会と午の敵・第二部. 予言の大潮: ヘーゲル, マルクスと午の余波. 未來社]

Popper, K. R. (1968a). The Logic of Scientific Discovery. Harper Torchbooks [大内義一・森博 訳 (1971-2). 科学的発見の論理 (上·下) 恒星社厚生閣]

Popper, K. R. (1968b). Conjectures and Refutations: The Growth of Scientific Knowledge. Harper Torchbooks. [藤本隆志. 石垣壽郎・森博訳 (1980). 推測と反駁 : 科学的知識の発展. 法政大 学出版局]

Popper, K. R. (1980). Evolution. New Scientist, 87: 611.

Popper, K. R. (1983). Realism and the Aim of Science. Routledge. [小河原誠・蔭山泰之・篠崎 研二訳 (2002). 実在論と科学の目的 (上·下) 岩波書店.] 
de Queiroz, K. and Poe, S. (2001). Philosophy and phylogenetic inference: A comparison of likelihood and parsimony mathods in the context of Karl Popper's writings on corroboration. Systematic Biology, 50: 305-321.

de Queiroz, K. and Poe, S. (2003). Failed refutations: Further comments on parsimony and likelihood methods and their relationship to Popper's degree of corroboration. Systematic Biology, 52: 352-367.

Rieppel, O. (2003). Popper and systematics. Systematic Biology, 52: 259-271.

Royall, R. M. (1997). Statistical Evidence: A Likelihood Paradigm. Chapman \& Hall / CRC.

Siddall, M. E. (2001). Philosophy and phylogenetic inference: A comparison of likelihood and parsimony methods in the context of Karl Popper's writings on corroboration. Cladistics, 17: 395-399.

Siddall, M. E. and Kluge, A. G. (1997). Probabilism and phylogenetic inference. Cladistics, 13: 313-336.

Simpson, G. G. and Roe, A. (1939). Quantitative Zoology: Numerical Concepts and Methods in the Study of Recent and Fossil Animals. McGraw-Hill.

Sober, E. (1988). Reconstructing the Past: Parsimony, Evolution, and Inference. The MIT Press. [三中信宏訳 (1996). 過去を復元する : 最節約原理・進化・推論. 蒼樹書房]

Sokal, R. R. and Rohlf, F. J. (1969). Biometry: The Principles and Practice of Statistics in Biological Research. W. H. Freeman.

Sokal, R. R. and Sneath, P. H. A. (1963). Principles of Numerical Taxonomy. W. H. Freeman.

Steel, M. and Penny, D. (2000). Parsimony, likelihood, and the role of models in molecular phylogenetics. Molecular Biology and Evolution, 17: 839-850.

Taper, M. L. and Lele, S. R. (eds.) (2004). The Nature of Scientific Evidence: Statistical, Philosophical, and Empirical Considerations. The University of Chicago Press

Thompson, D'A. W. (1942). On Growth and Form. Cambridge University Press.

Tuffley, C. and Steel, M. (1997). Links between maximum likelihood and maximum parsimony under a simple model of site substitution. Bulletin of Mathematical Biology, 59: 581-607.

Yang, Z. (2006). Computational Molecular Evolution. Oxford University Press. 